\title{
Proapoptotic effects of novel pentabromobenzylisothioureas in human leukemia cell lines
}

\author{
Mirosława Koronkiewicz • Zdzisław Chilmonczyk • \\ Zygmunt Kazimierczuk
}

Received: 3 January 2011/Accepted: 25 October 2011/Published online: 11 November 2011

(C) The Author(s) 2011. This article is published with open access at Springerlink.com

\begin{abstract}
A series of new pentabromobenzylisothioureas [ZKK-1-ZKK-5; (ZKKs)] carrying additional substituents on nitrogen atoms has been synthesized. The ZKKs were found to induce apoptosis in HL-60 (human promyleocytic leukemia) and K-562 (human chronic erythromyeloblastoid leukemia) cell lines in a concentration-dependent manner at low micromolar concentrations. ZKK-3 [ $\left(N, N^{\prime}-\right.$ dimethyl-S-2,3,4,5,6-pentabromobenzyl)isothiouronium bromide] showed the highest proapoptotic activity in HL-60 cells, whereas ZKK-2 [ $N$-methyl-S-(2,3,4,5,6pentabromobenzyl)isothiouronium bromide] was most effective in this respect in K-562 cells. During the ZKKsinduced apoptosis, an $85 \mathrm{kDa}$ fragment of cleaved PARP (caspase-3 and caspase-7 substrate) was detected in both cell lines tested. The studied compounds also decreased mitochondrial transmembrane potential in both these cell lines and caused the cells to accumulate in $G_{1}$ and at the $\mathrm{G}_{1} / \mathrm{S}$ border of the cell cycle in a concentration-dependent manner. These results show promise for their study as new compounds in the treatment of leukemia, after an appropriate preclinical toxicity profile.
\end{abstract}

Keywords Pentabromobenzylisothioureas . Pentabromobenzylisothiouronium · Apoptosis · Human leukemia cell lines · Flow cytometry

\footnotetext{
Z. Kazimierczuk ( $\square)$

Mossakowski Medical Research Centre,

5 Pawinskiego St., 02-106 Warsaw, Poland

e-mail: ZKazimierczuk@gmail.com

M. Koronkiewicz $\cdot$ Z. Chilmonczyk

Department of Cell Biology, National Medicines Institute,

30/34 Chełmska St., 00-725 Warsaw, Poland
}

\section{Introduction}

Isothioureas are a class of amphiphilic compounds carrying a highly basic isothiourea function of $\mathrm{pK}_{\mathrm{a}} \approx 10$. Therefore, at physiological $\mathrm{pH}$ these compounds exist in a protonated (cationic) form that may be important for their specific biological effects. In solid state they form salts of usually better water solubility then that of the substrates used for their synthesis.

Reports on anticancer activity of isothioureas are very scarce. $S$-(10-undecen-1-yl)isothiouronium iodide was found to be effective against Walker carcinoma cells in rats (Carmona and Gonzalez-Cadavid, 1978; Gonzalez-Cadavid and Herrera Quijada, 1974), and bisisothiouronium derivatives of thiophene were reported to show activity against Yoshida sarcoma (Gogte et al., 1967). Recently, a report showing proapoptotic activity of a number of pentabromobenzylisothiourea derivatives with substantial cytotoxicity toward human glioblastoma cells has been published. The efficacy of the latter compounds was higher than that of the well-known casein kinase 2 (CK2) inhibitor 4,5,6,7-tetrabromo- $1 H$-benzotriazole (TBB), and was similar to that of 4,5,6,7-tetrabromo- $1 H$-benzimidazole (TBI). Cell death induced in rat and human malignant glioma cells by the pentabromobenzylisothiourea derivatives was associated with a decrease in mitochondrial membrane potential and with activation of caspase- 3 and caspase-7 followed by PARP cleavage (Kaminska et al., 2009).

More attention was given to isothioureas as inhibitors of nitric oxide synthase (NOS) isoforms. These enzymes play a significant and multifaceted role in both physiology and pathology; therefore, there is an ongoing search for their effective inhibitors (Garvey et al., 1994; Jin et al., 2009; Rairigh et al., 1998; Kalish et al., 2002). For instance, some isothioureas show selectivity for neuronal NOS and a 
promise for utility in the treatment of neurodegenerative diseases (Schulz et al., 1997; Castano et al., 2008), whereas some selective inhibitors of inducible NOS, including few $S$-substituted isothioureas, were found effective as chemopreventive agents in rat tracheal epithelial cells treated with the carcinogen benzo $[a]$ pyrene (Sharma et al., 2002). We have recently reported that some substituted benzylisothioureas, including the prototype pentabromobenzylisothiourea, are potent inhibitors of $\mathrm{Ca}^{2+} /$ calmodulin-dependent NOSs (endothelial NOS and neuronal NOS) in normal rat brain homogenates (Kazimierczuk et al., 2010). Moreover, another group of $S$-benzylisothioureas has been recently shown to inhibit indoleamine-2,3-dioxygenase, which is overexpressed and may play an important role in a variety of illnesses, including cancer and some neurodegenerative diseases (Matsuno et al., 2010).

In this study we examined proapoptotic and cytostatic effects of the previously described $S$-(2,3,4,5,6-pentabromobenzyl)isothiourea (ZKK-1) and its four newly synthesized congeners ZKK-2, ZKK-3, ZKK-4, and ZKK-5 (ZKKs) in HL-60 (human promyleocytic leukemia) and K-562 (human chronic erythromyeloblastoid leukemia) cell lines.

\section{Materials and methods}

Chemistry

Melting points were determined in open capillary tubes on a model MFB-595-030G Gallenkamp melting point apparatus. ${ }^{1} \mathrm{H}-\mathrm{NMR}$ spectra were recorded on a Bruker AMX400 instrument at $25^{\circ} \mathrm{C}$. Chemical shifts are reported in ppm from internal tetramethylsilane standard. The solvent used for NMR spectra was deuteriodimethylsulfoxide. Elemental analyses were performed at the Faculty of Chemistry, Warsaw Technical University, using a Heraeus CHN-Rapid analyzer.

General procedure for the preparation of $N$-substituted $S$-(2,3,4,5,6-pentabromobenzyl)isothiouronium bromides (ZKK 1-5)

To a hot solution of thiourea derivative $(5.1 \mathrm{mmol})$ in anhydrous ethanol (20 mL) 2,3,4,5,6-pentabromobenzyl bromide $(5 \mathrm{mmol})$ was added. The mixture was refluxed for $20 \mathrm{~min}$ and then the solvent was partially evaporated to a final volume of about $10 \mathrm{~mL}$. This was left refrigerated overnight. The chromatographically pure crystals that formed were filtered off and washed with a small volume of cold ethanol/ethyl ether mixture $(1: 1, \mathrm{v} / \mathrm{v})$. For elemental analysis, a small amount of the product was recrystallized from ethanol. Synthesis scheme and chemical structure of ZKKs are shown in Fig. 1.

\section{S-(2,3,4,5,6-pentabromobenzyl)isothiouronium bromide (ZKK-1)}

Synthesis of this compound has been described previously (Kazimierczuk et al., 2010).

\section{N-Methyl-S-(2,3,4,5,6-pentabromobenzyl)isothiouronium bromide (ZKK-2)}

Yield: $88 \%$; mp $266-268^{\circ} \mathrm{C} .{ }^{1} \mathrm{H}-\mathrm{NMR}$ (DMSO-D ${ }_{6}$ ): $\delta=2.96\left(\mathrm{~s}, 3 \mathrm{H}, \mathrm{N}-\mathrm{CH}_{3}\right), 4.92\left(\mathrm{~s}, 2 \mathrm{H},-\mathrm{CH}_{2}-\right), 9.25,9.64$ and $9.96\left(3 \mathrm{bs}, 3 \mathrm{H}, \mathrm{NH}\right.$ and $\left.\mathrm{NH}_{2}\right)$. Anal. for $\mathrm{C}_{9} \mathrm{H}_{8} \mathrm{~N}_{2} \mathrm{SBr}_{6}$ (575.81): Calc. C: 16.49, H, 1.23, N, 4.27. Found C: 16.35 , $\mathrm{H}, 1.28, \mathrm{~N}, 4.16$.
Fig. 1 Synthesis and structure of $N$-substituted pentabromobenzylisothioureas (ZKKs)<smiles>BrCc1c(Br)c(Br)c(Br)c(Br)c1Br</smiles><smiles>[R]NC(=S)N[R]</smiles><smiles>CCOc1ccccc1</smiles>

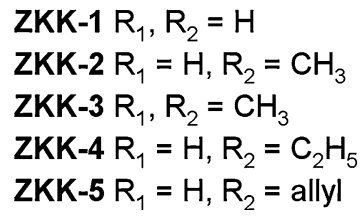


$N, N^{\prime}$-Dimethyl-S-(2,3,4,5,6-

pentabromobenzyl)isothiouronium bromide (ZKK-3)

Yield $85 \%$, mp $242-244{ }^{\circ} \mathrm{C} .{ }^{1} \mathrm{H}-\mathrm{NMR}$ (DMSO-D ${ }_{6}$ ): $\delta=3.00\left(\mathrm{~s}, 6 \mathrm{H}, 2 \times \mathrm{CH}_{3}\right), 4.91\left(\mathrm{~s}, 2 \mathrm{H},-\mathrm{CH}_{2}-\right), 9.42$ and $9.62(2$ bs, $2 \mathrm{H}, 2 \times \mathrm{NH})$. Anal. for $\mathrm{C}_{10} \mathrm{H}_{10} \mathrm{~N}_{2} \mathrm{SBr}_{6}$ (588.79): Calc. C: 17.94, H, 1.51, N, 4.18. Found C: 17.90, $\mathrm{H}, 1.55, \mathrm{~N}, 4.09$.

\section{$N$-Ethyl-S-(2,3,4,5,6-pentabromobenzyl)isothiouronium bromide (ZKK-4)}

Yield $77 \%$, mp $229-231{ }^{\circ} \mathrm{C}$. ${ }^{1} \mathrm{H}-\mathrm{NMR}$ (DMSO-D 6 ): $\delta=1.19\left(\mathrm{t}, 3 \mathrm{H}, J=7.2 \mathrm{~Hz},-\mathrm{CH}_{3}\right), 3.35$ (q, $2 \mathrm{H}$, overlap. HOD, $\mathrm{N}-\mathrm{CH}_{2}-$ ), 4.91 (s, $2 \mathrm{H},-\mathrm{CH}_{2}-$ ), 9.28, 9.60 and 9.40 (3bs, $3 \mathrm{H}, \mathrm{NH}$ and $\mathrm{NH}_{2}$ ). Anal. for $\mathrm{C}_{10} \mathrm{H}_{10} \mathrm{~N}_{2} \mathrm{SBr}_{6}$ (588.79): Calc. C: $17.94, \mathrm{H}, 1.51, \mathrm{~N}, 4.18$. Found C: $17.88, \mathrm{H}, 1.57$, $\mathrm{N}, 4.08$.

\section{$N$-Allyl-S-(2,3,4,5,6-pentabromobenzyl)isothiouronium bromide (ZKK-5)}

Yield $75 \%, \mathrm{mp} \quad 250-252^{\circ} \mathrm{C} .{ }^{1} \mathrm{H}-\mathrm{NMR}$ (DMSO-D 6 ): $\delta=4.02\left(\mathrm{~d}, 2 \mathrm{H}, J=4.7 \mathrm{~Hz},-\mathrm{N}-\mathrm{CH}_{2}\right), 4.94(\mathrm{~s}, 2 \mathrm{H}$, $\left.-\mathrm{CH}_{2}-\right), 5.26(\mathrm{~s}, 1 \mathrm{H},=\mathrm{CH}), 5.29(\mathrm{~d}, 1 \mathrm{H}, J=6.1 \mathrm{~Hz},=\mathrm{CH})$, $5.86(\mathrm{~m}, 1 \mathrm{H},-\mathrm{CH}=), 9.34,9.69$ and $10.15(3 \mathrm{bs}, 3 \mathrm{H}, \mathrm{NH}$ and $\mathrm{NH}_{2}$ ). Anal. for $\mathrm{C}_{11} \mathrm{H}_{10} \mathrm{~N}_{2} \mathrm{SBr}_{6}$ (600.80): C, 19.38, H, 1.48, $\mathrm{N}, 4.11$. Found: C, 19.29, H, 1.55, N, 4.03.

Antileukemic activity studies

\section{Cell lines and treatments}

HL-60 (human promyelocytic leukemia) cell line was obtained from the American Type Culture Collection (ATCC, Manassas, VA, USA), and K-562 (human chronic erythromyeloblastoid leukemia) cell line was obtained from the German Collection of Microorganisms and Cell Cultures (DSMZ). The cells were grown in RPMI-1640 medium (Gibco, Grand Island, NY, USA) supplemented with $10 \%(\mathrm{v} / \mathrm{v})$ of heat-inactivated fetal bovine serum (Gibco, Grand Island, NY, USA) and 1\% (v/v) of antibiotic-antimycotic solution (Gibco), at $37^{\circ} \mathrm{C}$ in a humidified atmosphere of $5 \% \mathrm{CO}_{2}$ in air. For experiments, $3 \mathrm{ml}$ aliquots per well of cell suspension in the same medium $\left(2.5 \times 10^{5}\right.$ cells $\left./ \mathrm{ml}\right)$, were seeded onto 6-well plates (Nunc, Denmark). All experiments were performed in exponentially growing cultures. The compounds studied were added to the cultures as solutions in dimethyl sulfoxide (DMSO; Sigma), and control cultures were treated with the same volume of the solvent. After culturing the cells with the studied compounds for 24 or $48 \mathrm{~h}$, the cells were collected and used for labeling.
Apoptosis assay by annexin V/propidium iodide (PI) labeling

Apoptosis was measured using the Annexin-V FITC Apoptosis Kit (Invitrogen). Twenty-four or $48 \mathrm{~h}$ posttreatment the cells were collected by centrifugation, rinsed twice with cold PBS and suspended in binding buffer at $2 \times 10^{6}$ cells $/ \mathrm{ml}$. One-hundred- $\mu \mathrm{l}$ aliquots of the cell suspension were labeled according to the kit manufacturer's instructions. In brief, annexin V-FITC and PI were added to the cell suspension and the mixture was vortexed and incubated for $15 \mathrm{~min}$ at room temperature in the dark. Then, $400 \mu$ of cold binding buffer was added and the cells were vortexed again and kept on ice. Flow cytometry measurements were performed within $1 \mathrm{~h}$ after labeling.

Morphological evaluation

After exposure to drugs, the cells were collected, washed with cold PBS and fixed at $-20^{\circ} \mathrm{C}$ in $70 \%$ ethanol for at least $24 \mathrm{~h}$. Next, ethanol was washed out and the cells were stained with $1.0 \mu \mathrm{g} / \mathrm{ml}$ DAPI and $20 \mu \mathrm{g} / \mathrm{ml}$ sulforhodamine 101. Cell morphology was evaluated using a BX60 fluorescence microscope equipped with a DP50 digital camera (Olympus, Japan).

Mitochondrial membrane potential $\left(\Delta \Psi_{\mathrm{m}}\right)$ assay

Mitochondrial membrane potential was assessed by flow cytometry using JC-1 (5,5',6,6'-tetrachloro-1, $1^{\prime}, 3,3^{\prime}$-tetraethylbenzimidazolocarbocyanine iodide; Sigma). JC-1 undergoes potential-dependent accumulation in mitochondria. In healthy cells, the dye accumulates in mitochondria, forming aggregates with red fluorescence (FL-2 channel), whereas in apoptotic cells the dye remains in the cytoplasm in a monomeric form and emits green fluorescence (FL-1 channel). Cells were harvested by centrifugation $48 \mathrm{~h}$ posttreatment, suspended in $1 \mathrm{ml}$ of complete culture medium at approximately $1 \times 10^{6}$ cells $/ \mathrm{ml}$ and incubated with $2.5 \mu \mathrm{lC}-1$ solution in DMSO $(1 \mathrm{mg} / \mathrm{ml})$ for $15 \mathrm{~min}$ at $37^{\circ} \mathrm{C}$ in the dark. Stained cells were washed with cold PBS, suspended in $400 \mu \mathrm{l}$ of PBS and then examined with a FACSCalibur flow cytometer equipped with CellQuest software (BD Biosciences, San Jose, CA, USA).

PARP cleavage assay

Caspase-3 and caspase-7 cleave poly(ADP-ribose) polymerase (PARP). PARP cleavage was detected by flow cytometry using Anti-PARP CSSA FITC Apoptosis Detection Kit (Invitrogen) according to manufacturer's protocol. The FITC-conjugated anti-PARP antibody employed in the kit specifically recognizes the $85 \mathrm{kDa}$ 

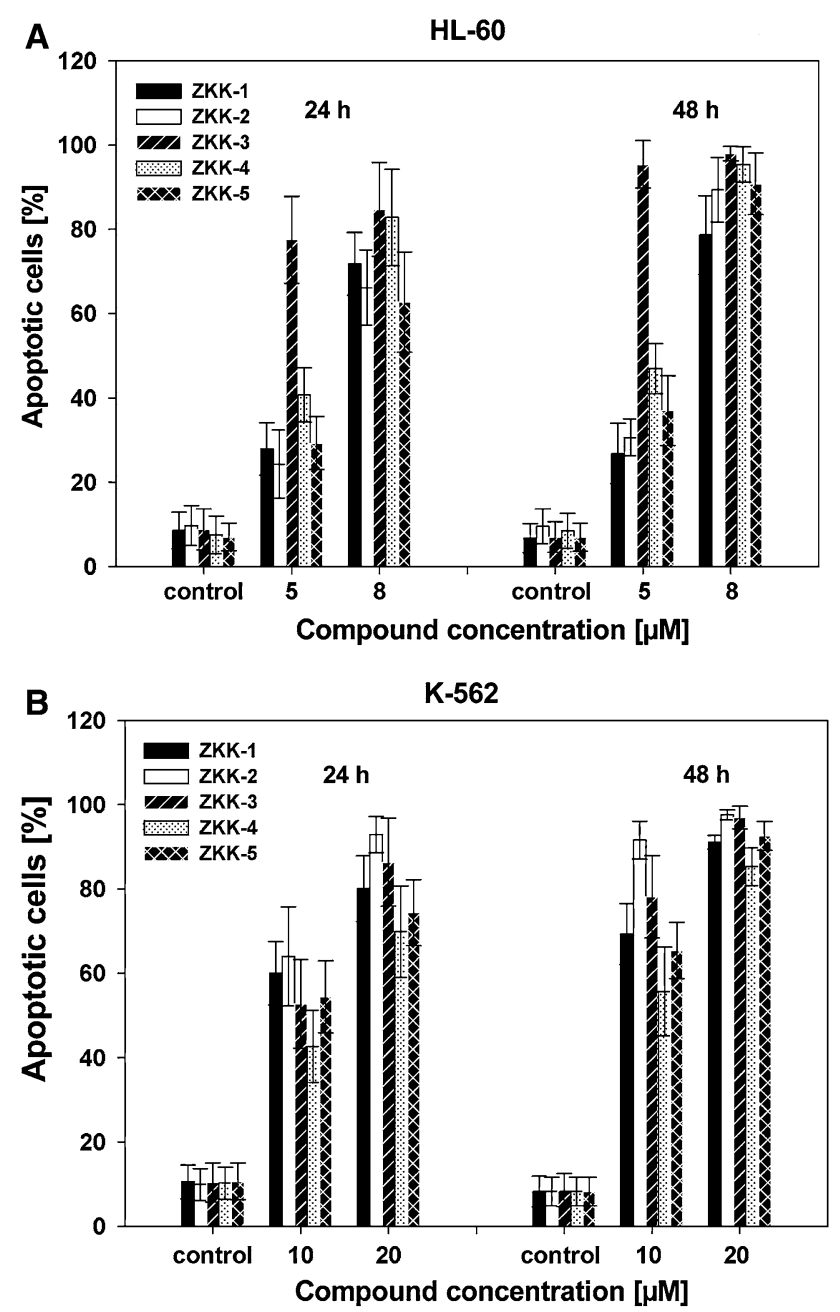

Fig. 2 Induction of apoptosis by ZKKs in HL-60 cells (a) and K-562 cells (b). The data were determined by FACS cytometer after 24 and $48 \mathrm{~h}$ treatment. Cells were stained with annexin V-FITC and PI. Each bar represents the mean $\pm \mathrm{SD}(n \geq 4)$

fragment of cleaved PARP. The cells meant for the assay were harvested $48 \mathrm{~h}$ post-treatment and washed twice with PBS just before use. The level of cleaved PARP protein was expressed as fluorescence intensity that was assessed using CellQuest and the free WinMDI software package written by Joseph Trotter of the Scripps Institute (La Jolla, CA, USA).

\section{Cell cycle analysis}

After exposure to the tested compounds, the cells were washed with cold PBS and fixed at $-20^{\circ} \mathrm{C}$ in $70 \%$ ethanol for at least $24 \mathrm{~h}$. Next, the cells were washed free of ethanol and stained with $50 \mu \mathrm{g} / \mathrm{ml} \mathrm{PI}$ and $100 \mu \mathrm{g} / \mathrm{ml}$ RNase solution in PBST (PBS supplemented with $0.1 \% \mathrm{v} / \mathrm{v}$ Triton $\mathrm{X}-100$ ) by 30 min incubation in the dark at room temperature. Cell DNA content and the distribution of the cells in different phases of the cell cycle were determined by flow cytometry employing MacCycle (Phoenix Flow Systems, San Diego, CA, USA) and CellQuest software packages.

Flow cytometry

Flow cytometry analyses were run on a FACSCalibur flow cytometer (BD Biosciences, San Jose CA, USA), and analyzed by CellQuest software (BD Biosciences, San Jose, CA, USA) and WinMDI 2.9 software. The DNA histograms obtained were analyzed using the MacCycle software.

\section{Results \\ Chemistry}

The $N$-substituted pentabromobenzylisothioureas were obtained following the direct strategy shown in Fig. 1. The reaction was performed using pentabromobenzyl bromide and the respective thiourea. The products-isothiouronium bromides-crystallized from the reaction mixture after concentrating. The compounds were characterized using ${ }^{1} \mathrm{H}-\mathrm{NMR}$ and elemental analyses.
Fig. 3 Morphology

(fluorescence microscopy employing DAPI/ sulforhodamine 101 labeling) of HL-60 cells cultured for $48 \mathrm{~h}$ in the absence (control, a) and presence of ZKK-3 (8 $\mu \mathrm{M}, \mathbf{b})$. Arrows indicate apoptotic nuclei
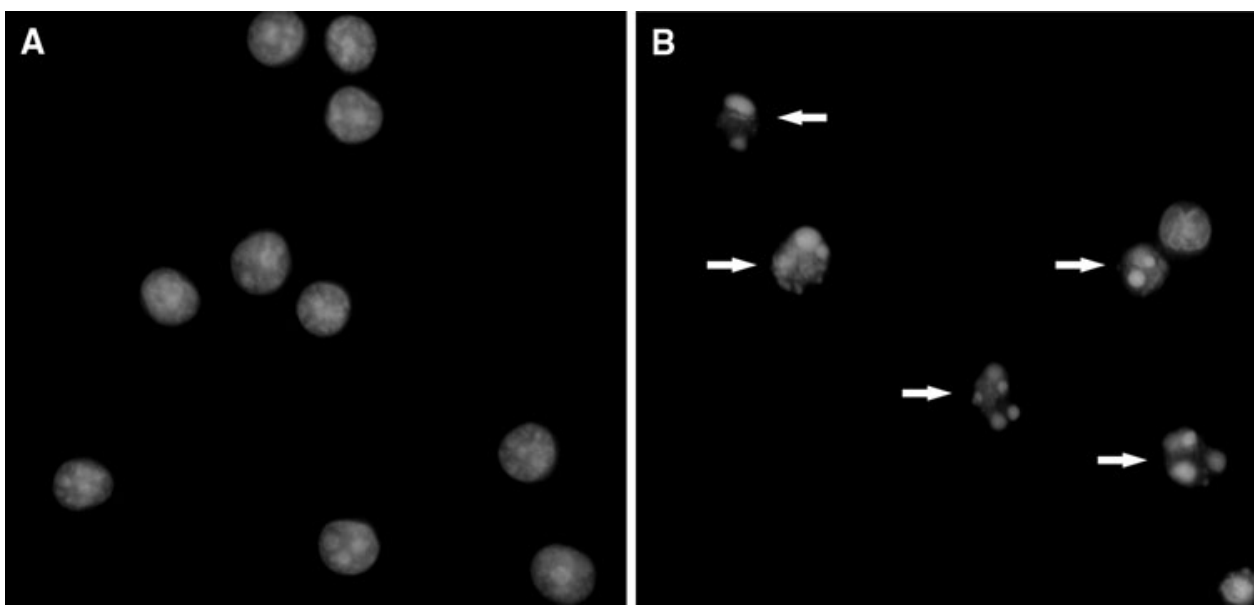


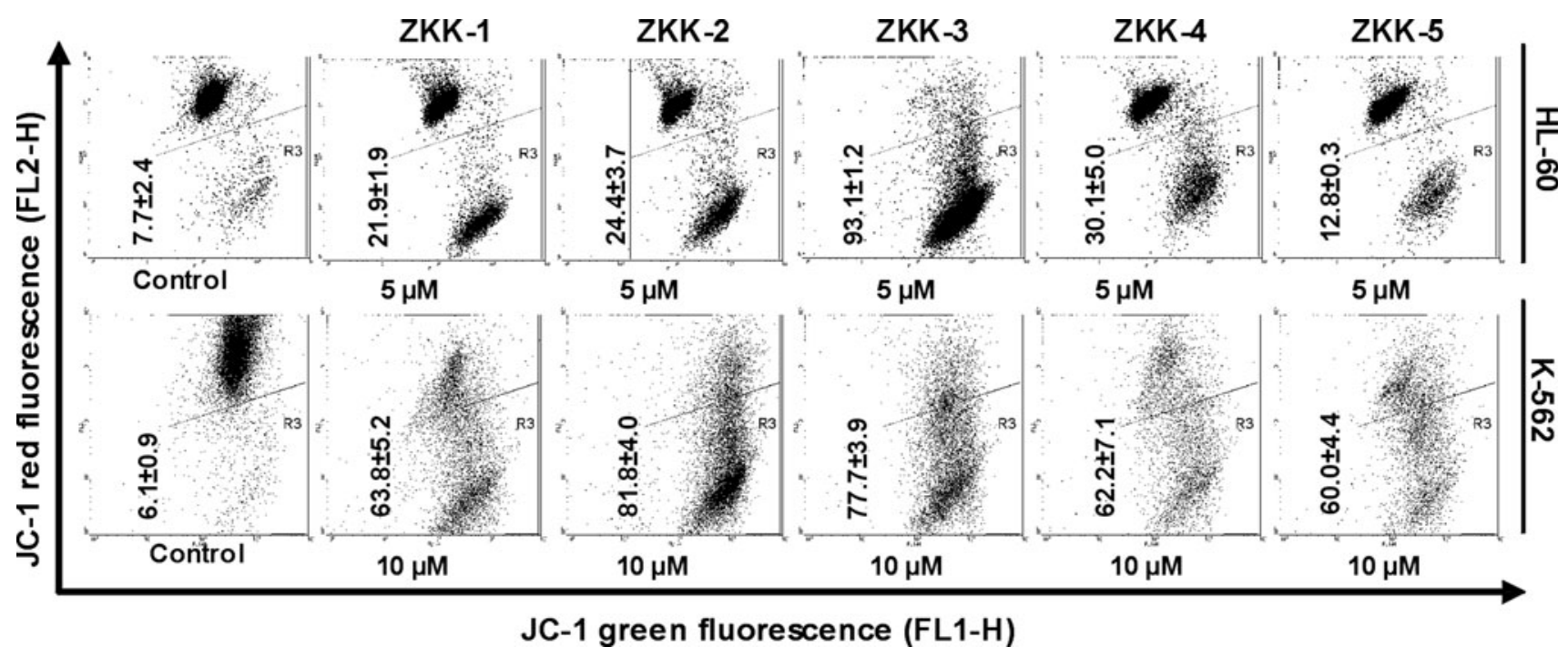

Fig. 4 Representative flow cytograms demonstrating changes in mitochondrial membrane potential $\left(\Delta \Psi_{\mathrm{m}}\right)$ of HL-60 cells (upper panels) and K-562 cells (lower panels) induced by $48 \mathrm{~h}$ culturing with various ZKKs compounds. The cells were stained with JC-1 dye. The cells in the lower right (R3) quadrant showed increased red-to-green fluorescence ratio (apoptotic cells)

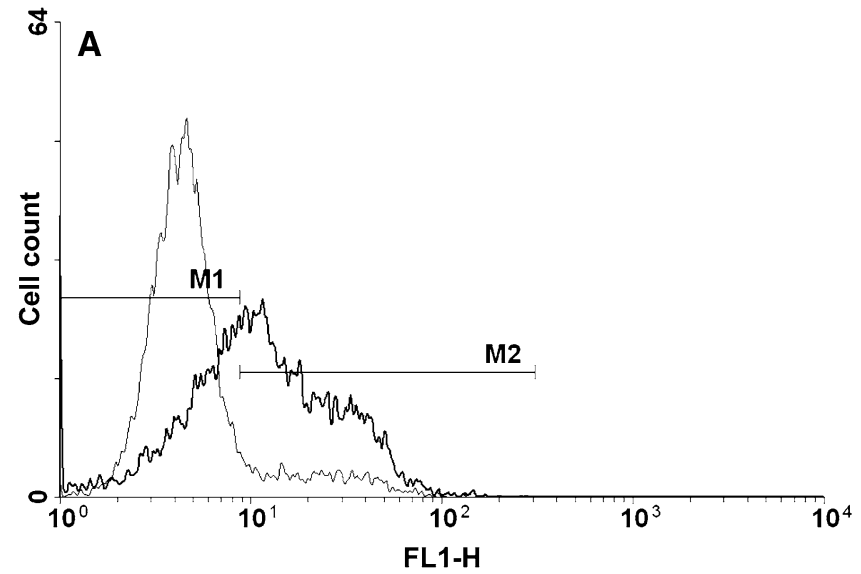

Fig. 5 Effect of ZKKs on proteolytic cleavage of PARP protein in cells were exposed for $48 \mathrm{~h}$ to ZKKs. Representative histograms showing increased level of $85 \mathrm{kDa}$ fragment of PARP protein indicating induction of apoptosis after ZKKs treatment. a: Histogram of HL-60 control cells and overlay histogram of treated cells at $8 \mu \mathrm{M}$

Induction of apoptosis by ZKKs in HL-60 and K-562 leukemia cells

ZKKs compounds induced apoptosis in both cell lines utilized, but the effect was more prominent in HL60 cells (Fig. 2). The observed apoptotic effect was doseand time-dependent. ZKK-3 [ $\left(N, N^{\prime}\right.$-dimethyl-S-2,3,4,5, 6-pentabromobenzyl)isothiouronium bromide] was the most effective in HL-60 cell line, whereas ZKK-2 [ $N$-methyl-S-(2,3,4,5,6-pentabromobenzyl)isothiouronium bromide] showed the most potent cytotoxic apoptotic effect

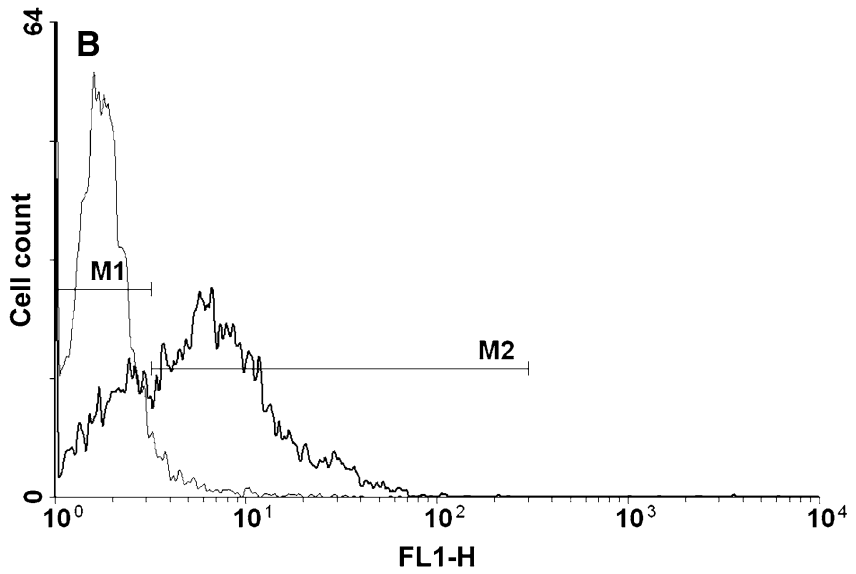

ZKK-3. b: Histogram of K-562 control cells and overlay histogram of treated cells at $10 \mu \mathrm{M}$ ZKK-2. Marker M1 designates negative cell populations whereas M2 designates positive cell populations (indicate apoptosis). Thin line control cells, thick line ZKK-treated cells

in K-562 cells. Fluorescence microscopy showed typical concentrating chromatin and apoptotic bodies' formation (Fig. 3).

Changes in mitochondrial membrane potential $\left(\Delta \Psi_{\mathrm{m}}\right)$

Analysis of the respective cytograms (for a representative cytogram see Fig. 4) showed that the tested compounds caused mitochondrial membrane depolarization (as evidenced by increased green-to-red fluorescence intensity ratio) in both cell lines studied. 


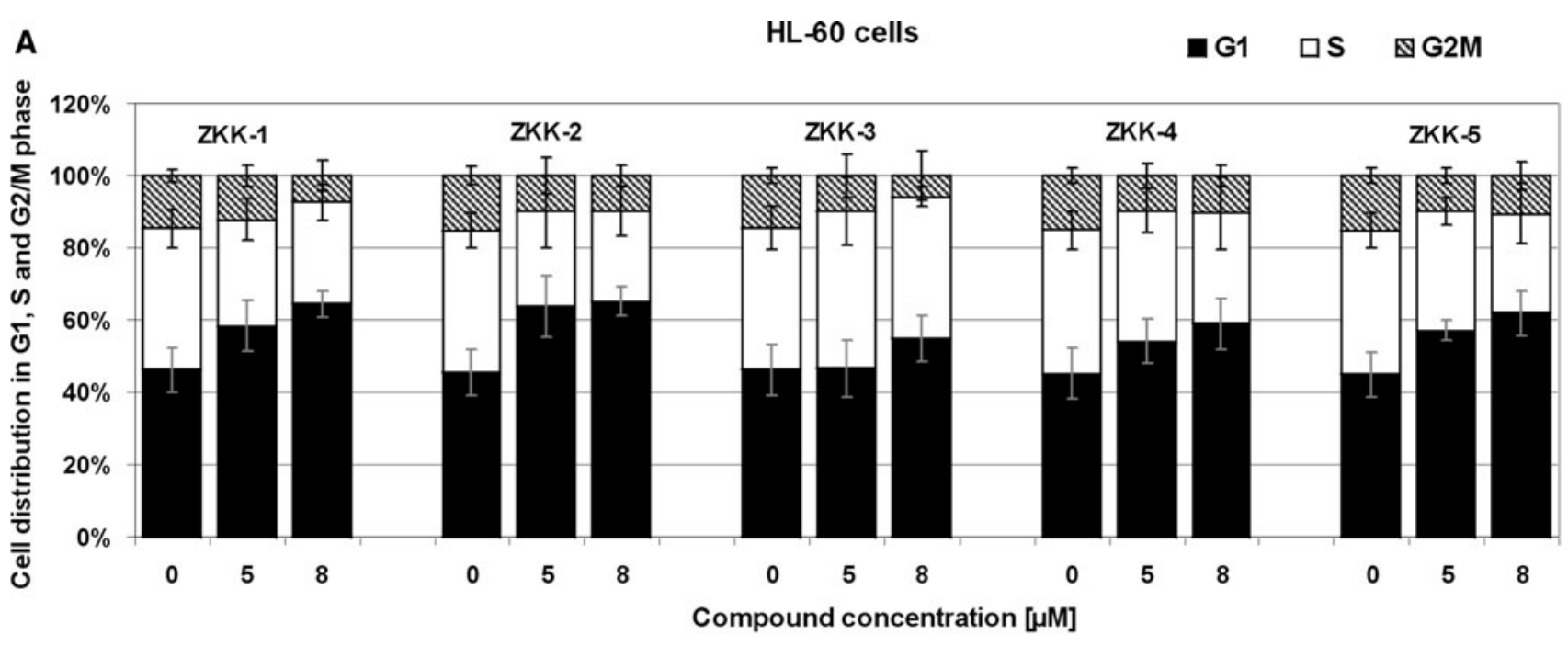

B

$\mathrm{K}-562$ cells

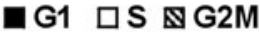

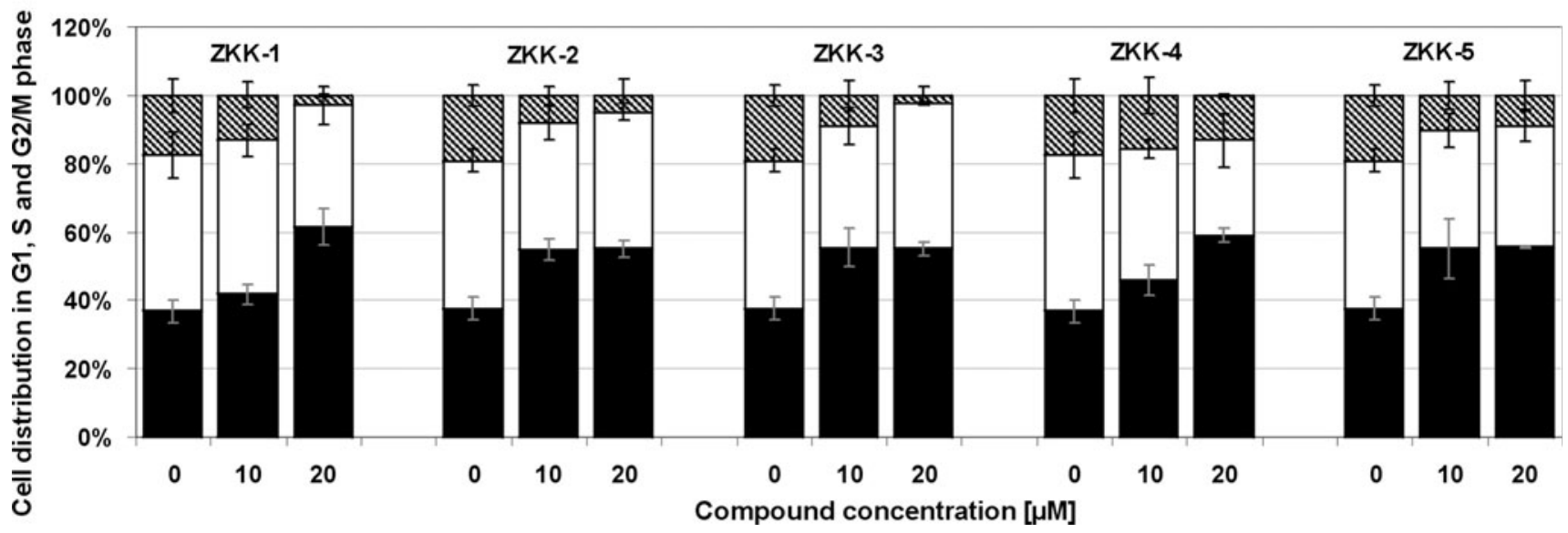

Fig. 6 Changes in cell cycle progression in HL-60 (a) and K-562 (b) cells after $48 \mathrm{~h}$ treatment with ZKKs. Each bar represents the mean $\pm \mathrm{SD}(n \geq 4)$. The data obtained from FACSCalibur flow

\section{ZKKs-induced cleavage of PARP protein}

The enhancement of apoptosis was confirmed by detecting PARP cleavage after $48 \mathrm{~h}$ incubation with the tested compounds. During ZKKs-induced apoptosis, the presence of $85 \mathrm{kDa}$ PARP fragments was revealed in both cell lines with the use of specific antibody (Fig. 5).

\section{Effect of ZKKs on cell cycle progression}

Figures $6 \mathrm{a}, \mathrm{b}$, and 7 demonstrate changes in the cell cycle progression of HL-60 and K-562 cells after $48 \mathrm{~h}$ incubation with the tested compounds. The compounds exerting cytostatic effect caused a concentration-dependent accumulation of cells in $G_{1}$ and at the border of $G_{1}$ and $S$ phases, decreasing the number of cells in the $\mathrm{G}_{2} \mathrm{M}$ phase of the cell cycle. cytometer were analyzed using MacCycle software to determine the percentage of cells in each phase of the cell cycle

\section{Discussion}

We decided to synthesize modified pentabromobenzylisothioureas in a search for new inhibitors of the antiapoptotic enzyme casein kinase 2 (CK2), structurally similar to such known polyhalogenobenzimidazole CK2 inhibitors as 4,5,6,7-tetrabromobenzimidazole (TBI) or 4,5,6,7-tetrabromo-2-dimethylaminobenzimidazole (DMAT) (Szyszka et al., 1995; Pagano et al., 2004; Gianoncelli et al., 2009). We expected that the new compounds would show the advantage of increased water solubility while retaining high CK2 inhibitory activity. However, the novel compounds showed only moderate CK2 inhibitory activity ( $\mathrm{K}_{\mathrm{i}} \approx 4 \mu \mathrm{M}$, Dr. F. Meggio, personal communication), whereas, surprisingly, they revealed a considerable antileukemic action in vitro. It should be noted that other known benzylisothioureas with substituents in the benzene 


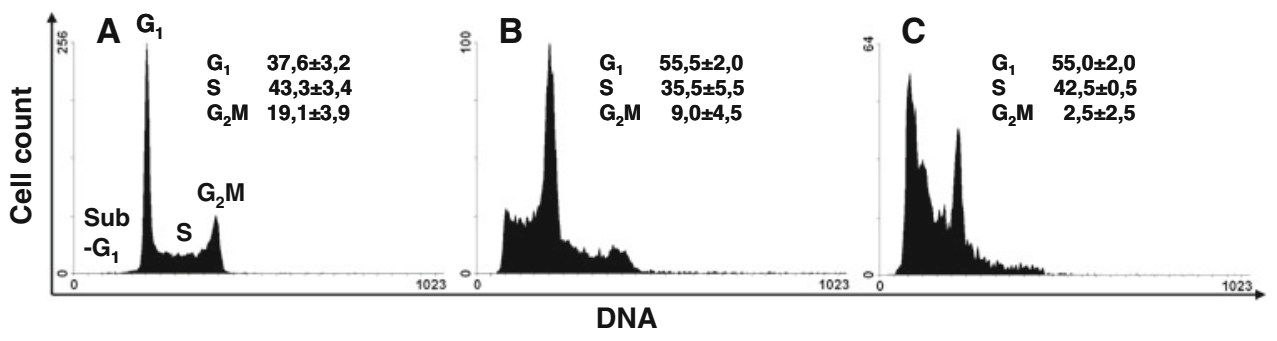

Fig. 7 Exemplary DNA histograms of K-562 cells treated for $48 \mathrm{~h}$ with ZKK-3. The data obtained from FACSCalibur flow cytometer and analyzed using MacCycle software to determine the percentage of

part of the molecule (for example, 2,3,4,5,6-pentafluoroand 3,4- and 2,4-dichlorobenzylisothioureas) showed only weak cytotoxic activity. Apparently, the introduction of a bulky substituent (e.g., phenyl or benzyl group) at one of the nitrogen atoms considerably reduces cytotoxicity of pentabromobenzylisothioureas (data not shown).

As we previously reported, modified benzylisothioureas are also inhibitors of the $\mathrm{Ca}^{2+}$ /calmodulin-dependent $\mathrm{NO}$ synthase (Kazimierczuk et al., 2010). The role of NO in cancer initation and progression is still debated and it is not yet decided whether NO should be considered as a potential anticancer agent or instead a carcinogen (Mocellin, 2009). When comparing the NOS inhibitory activity and anticancer activity of other tested benzylisothioureas, we did not find a straightforward correlation between these attributes (data not shown).

ZKKs showed considerable cytotoxic and cytostatic effects in both HL-60 (human promyleocytic leukemia) and K-562 (human chronic erythromyeloblastoid leukemia) cells. Proapoptotic effects were higher in HL-60 than in K-562 cells. Apoptotic death was associated with increased depolarization of the mitochondrial membrane and with increase in the level of $85 \mathrm{kDa}$ fragments of PARP protein. The latter effect is an indirect measure of activation of the effector caspase-3 and caspase-7 that proteolytically cleave native $116 \mathrm{kDa}$ PARP protein into 85 and $25 \mathrm{kDa}$ fragments. Decreasing mitochondrial transmembrane potential suggests an activation of "the intrinsic" pathway of apoptosis by the tested compounds.

It should be emphasized that compounds ZKKs induced apoptosis in the K-562 cells derived from a woman with chronic myeloid leukemia (CML) in blast crisis (Lozzio and Lozzio, 1975; McGahon et al., 1994). The K-562 cells carry the Philadelphia $(\mathrm{Ph})$ chromosome (Lozzio and Lozzio, 1975). The result of this chromosomal translocation is formation of the oncogenic $B c r-A b l$ fusion gene that is constitutively active. The product of the $B c r-A b l$ gene is a protein with tyrosine kinase activity. Bcr-Abl-expressing leukemic cells show resistance to apoptosis induced by chemotherapeutic drugs (McGahon et al., 1994), which cells in each phase of the cell cycle. a: Control (no ZKK-3 added); b: $10 \mu \mathrm{M}$ ZKK-3; c: $20 \mu \mathrm{M}$ ZKK-3

seems to be related to overexpression of the antiapoptotic protein Bcl- $\mathrm{x}_{\mathrm{L}}$ (Horita et al., 2000). In general, K562 cells are highly resistant to multiple anticancer agents and easily transform to drug-resistant lines during treatment by novel drugs (McGahon et al., 1994; Bedi et al., 1995; AmaranteMendes et al., 1998).

\section{Concluding remarks}

Our results suggest that $N$-substituted pentabromobenzylisothioureas might be promising anticancer agents. The study on anticancer activity of this compound class in solid tumors is in progress, and further investigations are needed to evaluate their clinical potential.

Acknowledgment This study was supported by the Ministry of Science and Higher Education (Poland) grants: PBZ-MIN 014/P05/ 2004 and N N209 371439.

Open Access This article is distributed under the terms of the Creative Commons Attribution Noncommercial License which permits any noncommercial use, distribution, and reproduction in any medium, provided the original author(s) and source are credited.

\section{References}

Amarante-Mendes GP, Naekyung KC, Liu L, Huang Y, Perkins CL, Green DR, Bhalla K (1998) Bcr-Abl exerts its anti-apoptotic effect against diverse apoptotic stimuli through blockage of mitochondrial release of cytochrom $\mathrm{C}$ and activation of caspase3. Blood 91:1700-1705

Bedi A, Barber JP, Bedi GC, El-Deiry WS, Sidransky D, Vala MS, Akhtar AJ, Hilton J, Jones RJ (1995) BCR-ABL-mediated inhibition of apoptosis with delay of G2M transition after DNA damage: a mechanism of resistance to multiple anticancer agents. Blood 86:1148-1158

Carmona A, Gonzalez-Cadavid NF (1978) Comparative effect of a family of substituted thiopseudoureas on protein synthesis by rat liver and Walker carcinoma ribosomes. Chem Biol Interact 22:309-327

Castano T, Encinas A, Perez C, Castro A, Campillo NE, Gil C (2008) Design, syntheses, and evaluation of potential inhibitors of nitric oxide synthase. Bioorg Med Chem 16:6193-6206 
Garvey EP, Oplinger JA, Tanaoury GJ, Sherman PA, Fowler M, Marshall S, Harmon MF, Paith JE, Furfine ES (1994) Potent and selective inhibition of human nitric oxide synthases. Inhibition by non-amino acid isothioureas. J Biol Chem 269:26669-26676

Gianoncelli A, Cozza G, Orzeszko A, Meggio F, Kazimierczuk Z, Pinna LA (2009) Tetraiodobenzimidazoles are potent inhibitors of protein kinase CK2. Bioorg Med Chem 17:7281-7289

Gogte VN, Shah LG, Tilak BD, Gadekar KN, Sahasrabudhe MB (1967) Synthesis of potential anticancer agents I: synthesis of substituted thiophenes. Tetrahedron 23:2437-2441

Gonzalez-Cadavid NF, Herrera Quijada F (1974) Inhibition of translation in liver polyribosomes by a new substituted thiopseudourea with antitumor action. Biochem J 138:129-141

Horita M, Andreu EJ, Benito A, Arbona C, Sanz C, Benet I, Prosper F, Fernandez-Luna JL (2000) Blockade of the Bcr-Abl kinase activity induces apoptosis of chronic myelogenous leukemia cells by suppressing signal transducer and activator of transcription 5-dependent expression of Bcl-XL. J Exp Med 191:977-984

Jin GH, Lee DY, Cheon YJ, Gim HJ, Kim DH, Kim HD, Ryu JH, Jeon R (2009) Synthesis of phenylisothiourea derivatives as inhibitors of NO production in LPS activated macrophages. Bioorg Med Chem Lett 19:3088-3092

Kalish BE, Bock NA, Davis WL, Rylett RJ (2002) Inhibitors of nitric oxide synthase attenuate nerve growth factor mediated increases in choline acetyltransferase expression in PC 12 cells. J Neurochem 81:624-635

Kaminska B, Ellert-Miklaszewska A, Oberbek A, Wisniewski P, Kaza B, Makowska M, Bretner M, Kazimierczuk Z (2009) Efficacy and mechanism of anti-tumor action of new potential CK2 inhibitors toward glioblastoma cells. Int J Oncol 35: $1091-1100$

Kazimierczuk Z, Chalimoniuk M, Laudy AE, Moo-Puc R, CedilloRivera R, Starosciak BJ, Chrapusta SJ (2010) Synthesis and antimicrobial and nitric oxide synthase inhibitory activities of novel isothiourea derivatives. Arch Pharm Res 36:821-830
Lozzio CB, Lozzio BB (1975) Human chronic myelogenous leukemia cell-line with positive Philadelphia-chromosome. Blood 45: 321-334

Matsuno K, Takai K, Isaka Y, Unno Y, Sato M, Takikawa O, Asai A (2010) S-benzylisothiourea derivatives as small-molecule inhibitors of indoleamine-2, 3-dioxygenase. Bioorg Med Chem Lett 20:5126-5129

McGahon A, Bissonnette R, Schmitt M, Cotter KM, Green DR, Cotter TG (1994) BCR-ABL maintains resistance of chronic myelogenous leukemia cells to apoptotic cell death. Blood 83:1179-1187

Mocellin S (2009) Nitric oxide: Cancer target or anticancer agent? Curr Cancer Drug Targets 9:214-236

Pagano MA, Andrzejewska M, Ruzzene M, Sarno S, Cesaro L, Bain J, Elliott M, Meggio F, Kazimierczuk Z, Pinna LA (2004) Optimization of protein kinase CK2 inhibitors derived from 4,5,6,7-tetrabromobenzimidazole. J Med Chem 47:6239-6247

Rairigh RL, Le Cras TD, Ivy DD, Kinsella JP, Richter G, Horan MP, Fan ID, Abman SH (1998) Role of inducible nitric oxide synthase in regulation of pulmonary vascular tone in the late gestation ovine fetus. J Clin Invest 101:15-21

Schulz JB, Matthews RT, Klockgether T, Dichgans J, Beal MF (1997) The role of mitochondrial dysfunction and neuronal nitric oxide in animal models of neurodegenerative diseases. Mol Cell Biochem 174:193-197

Sharma S, Wilkinson BP, Gao P, Steele VE (2002) Differential activity of NO synthase inhibitors as chemopreventive agents in a primary rat tracheal epithelial cell transformation system. Neoplasia 4:332-336

Szyszka R, Grankowski N, Felczak K, Shugar D (1995) Halogenated benzimidazoles and benzotriazoles as selective inhibitors of protein kinases CK I and CK II from Saccharomyces cerevisiae and other sources. Biochem Biophys Res Commun 208:418-424 